\title{
A revision of the genus Achaearanea (Araneae: Theridiidae)
}

\author{
Hajime Yoshida \\ Yamagata Prefectural Museum, Kajo-machi 1-8, Yamagata-shi, 990-0826 Japan \\ E-mail: yoshidahaji@pref.yamagata.jp
}

\begin{abstract}
The genus Achaearanea Strand, 1929 (Theridiidae) is revised. Two genera, Henziectypus Archer, 1946 and Cryptachaea Archer, 1946, are revived from the synonymy of Achaearanea. Parasteatoda Archer, 1946 is recognized as an independent genus. Redefinitions and species lists of four genera, Achaearanea, Henziectypus, Cryptachaea and Parasteatoda, are given. Nine species of Henziectypus, 61 species of Cryptachaea, and 37 species and a subspecies of Parasteatoda, are respectively transferred from Achaearanea to the suitable genera.
\end{abstract}

Key words - taxonomy, Achaearanea, Henziectypus, Cryptachaea, Parasteatoda, Theridiidae, new combination

The genus Achaearanea was established by Strand in 1929 because the genus Achaea O. Pickard-Cambridge, 1882 was preoccupied by the genus of Lepidoptera, Achaea Hübner, 1823. On the other hand, Archer (1946) established a new genus, Henziectypus, and two new subgenera of Theridion, Cryptachaea and Parasteatoda. Shortly after that, he elevated the subgenera to the generic position (Archer 1950). However, these three genera were synonymized with Achaearanea by Levi (1955), and have not been used by any arachnologists. After the revision of the genus Achaearanea made by Levi, many species have been transferred to or described under this genus. At present, 146 species and a subspecies of Achaearanea are known from the world (Platnick 2008).

In my previous papers (Yoshida 1983, 2000, 2001, 2003), I followed the definition of Achaearanea proposed by Levi, and used the generic name for 13 Japanese species. He defined the genus Achaearanea chiefly on the basis of the characteristics of palpal organs: median apophysis (theridiid tegular apophysis devoid of seminal duct) broadly attached to embolus or tegulum, and radix (theridiid tegular apophysis containing seminal duct) absent. In spite of them, type species of Achaearanea, A. trapezoidalis (Taczanowski, 1873) widely distributed in South America, is a peculiar species and has many different characteristics compared with most other ones and also Japanese ones of this genus listed in Platnick (2008).

In 2006, Saaristo removed Parasteatoda from the synonymy, and redescribed two species, P. mundula (L. Koch, 1872) and P. tepidariorum (C. L. Koch, 1841). Two subspecies of them, P. mundula papuana (Chrysanthus, 1963) and P. tepidariorum australis (Thorell, 1895), were also listed by Platnick (2008). However, the genus Parasteatoda has not been recognized in general.

In this paper, I also recognize Parasteatoda as an independent genus and newly revive two genera, Cryptachaea and Henziectypus, from the synonymy of Achaearanea. I consider that the differences among the four genera correspond to the level usually recognized between the genera in the family Theridiidae. Redefinitions and lists of the species of four genera are given below. According to my examination, only three species belong to Achaearanea, and most of all the species described under Achaearanea are transferred to the other genera, Henziectypus, Cryptachaea and Parasteatoda. Remaining species are excluded in this paper, because at present I can't determine their generic status.

Key to the genera, Achaearanea, Henziectypus, Cryptachaea and Parasteatoda

1a. Duct of female internal genitalia thick near the opening, thin and coiled near spherical seminal receptacle; paracymbium of male palpus hooked; embolus narrow and very long, supported by cymbium $\cdots \cdot \cdot$ Achaearanea 1b. Duct of female internal genitalia not coiled near seminal receptacle; paracymbium of male palpus hooded; embolus not so long and not supported by cymbium $\cdots \cdots \cdot 2$

2a. Epigynum without posterior lobe, depression distinct; cymbium of male palpus not extend beyond the alveolus; tegulum not large and depressed; subtegulum large Parasteatoda

2b. Epigynum usually with posterior lobe, depression indistinct; cymbium of male palpus extend beyond the alveolus; tegulum large and spherical; subtegulum shallow

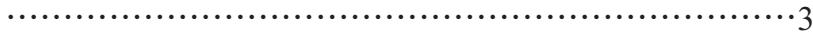

3a. Median apophysis of male palpus broadly attached to tegulum; cymbium distally with a horn projection

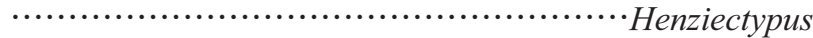

3b. Median apophysis of male palpus attached to embolus; 
cymbium without horn projection $\cdots \cdots \cdots \cdot \cdots \cdot$ Cryptachaea

\section{Achaearanea Strand, 1929}

Achaea O. Pickard-Cambridge 1882, p. 428, preoccupied by Achaea Hübner, 1823 (Lepidoptera); Archer 1950, p. 17.

Achaearanea Strand 1929, p. 11, new name for Achaea O. Pickard-Cambridge, 1882.

Carapace oval. Abdomen suboval with a posterior large tip. Female genitalia: epigynum with a depression and two openings; duct thick near the opening, thin and coiled near spherical seminal receptacle. Male palpus: cymbium with large distal projections deeply divided into two projections; paracymbium hooked, on the lateral edge of cymbium; embolus narrow and very long, supported by cymbium; conductor laterally projecting; median apophysis attached to embolus and forming one sclerite with it; tegulum large and spherical; subtegulum small.

General appearances and genital organs of three species belonging to this genus were illustrated by Levi (1955, figs. 7-13; 1963, figs. 1-6).

Diagnosis. This genus is easily distinguished from Henziectypus, Cryptachaea and Parasteatoda by the cymbium of male palpus with hooked paracymbium, the embolus narrow and very long, supported by cymbium, and the duct of female internal genitalia thin and coiled near seminal receptacle. This genus is similar to Chrysso in the shape of the abdomen, but is distinguished from the latter by genital organs and relatively short legs.

Type species. Achaea insignis O. Pickard-Cambridge, 1882 (=Argyrodes trapezoidalis Taczanowski, 1873).

Species included. As far as I know, only three species, Achaearanea hieroglyphia (Mello-Leitão, 1940), $A$. trapezoidalis (Taczanowski, 1873) and A. tingo Levi, 1963, are confirmed to belong to this genus. Most of all the species of Achaearanea listed by Platnick (2008) should be transferred to the different genera.

Distribution. Central and South America (Levi 1955, 1959, 1963).

\section{Henziectypus Archer, 1946}

Henziectypus Archer 1946, p. 51; Archer 1950, p. 16.

Carapace oval. Abdomen nearly spherical, usually higher than long. Female genitalia: epigynum usually with posterior lobe and without depression; two small openings present anterior to lobe; duct very short; seminal receptacles nearly spherical to bean-shape. Male palpus: cymbium distally with a horn projection; paracymbium hooded, basally on a horn projection of cymbium; embolus and conductor short; median apophysis small, broadly attached to tegulum; tegulum nearly spherical; subtegulum shallow and ring-like, usually invisible from ventral side.

General appearances and genital organs of ten species belonging to this genus were illustrated by Levi (1955, figs. 14-38; 1959, figs. 1-23).

Diagnosis. This genus most resembles Cryptachaea, but is distinguished from the latter by the median apophysis broadly attached to tegulum. Discriminating characteristics from Achaearanea and Parasteatoda are given under the descriptions of them.

Type species. Theridion globosum Hentz, 1850.

Species included. Ten species are known from North and Central America, and nine of them are newly transferred to this genus.

Henziectypus annus (Levi, 1959), H. apex (Levi, 1959), H. conjunctus (Gertsch \& Mulaik, 1936), H. florendidus (Levi, 1959), H. florens (O. Pickard-Cambridge, 1886), $H$. globosus (Hentz, 1850), H. hermosillo (Levi, 1959), $H$. serax (Levi, 1959), H. schullei (Gertsch \& Mulaik, 1936) and $H$. turquino (Levi, 1959). Other than H. globosus (Hentz, 1850), all new combination.

Distribution. North and Central America (Levi 1955, 1959, 1963).

\section{Cryptachaea Archer, 1946}

[Japanese name: Iwama-himegumo zoku]

Cryptachaea Archer 1946, p. 36, established as a subgenus of Theridion; Archer 1950, p. 14, elevated to generic position.

Carapace oval. Abdomen nearly spherical usually with a small posterior projection, longer than high, sometimes higher than long. Female genitalia: epigynum sometimes with posterior lobe; depression indistinct; two small openings present; duct short; seminal receptacles nearly spherical to bean shaped. Male palpus: cymbium extend beyond the alveolus; paracymbium hooded; embolus usually short except for $C$. porteri, C. serenoae etc.; conductor short; median apophysis attached to embolus with which it forms one sclerite; tegulum large and spherical; subtegulum shallow and ring-like.

General appearances and genital organs of many species belonging to this genus were illustrated by Levi (1955, figs. 39-68, 71-82; 1959, figs. 24-44, 53-56, 61-69; 1963, figs. 7-114) and Buckup \& Marques (1991, figs. 1-16).

Diagnosis. This genus resembles Henziectypus and Parasteatoda, but is distinguished from Henziectypus by median apophysis attached to embolus with which it forms one sclerite, from Parasteatoda by cymbium extend beyond alveolus, tegulum spherical, and subtegulum shallow and ring-like.

Saaristo (2006) established a new genus Spinembolia based on a monotype, S. clabna (Roberts, 1978) described from the Seychelles. Structures of male palpus and epigynum of S. clabna (cf. Saaristo 2006, figs. 81-82) resembles those of Cryptachaea. Differences between Spinembolia and Cryptachaea are not clear.

Type species. Theridion catapetraeum Gertsch \& Archer, 1942 (= Theridium porteri Banks, 1896). 
Species included. Sixty-six species are known from the world and 64 of them are newly transferred to this genus. This genus chiefly occurs in America, so a completely revision of this genus was not done.

Cryptachaea acoreensis (Berland, 1932), C. alacris (Keyserling, 1884), C. altiventer (Keyserling, 1884), C. ambera (Levi, 1963), C. analista (Levi, 1963), C. anastema (Levi, 1963), C. azteca (Chamberlin \& Ivie, 1936), C. banosensis (Levi, 1963), C. barra (Levi, 1963), C. bellula (Keyserling, 1891), C. caliensis (Levi, 1963), C. canionis (Chamberlin \& Gertsch, 1929), C. caqueza (Levi, 1963), C. chilensis (Levi, 1963), C. chiricahua (Levi, 1955), C. cinnabarina (Levi, 1963), C. diamantina (Levi, 1963), C. dromedariformis (Roewer, 1942), C. eramus (Levi, 1963), C. fresno (Levi, 1955), C. gigantea (Keyserling, 1884), C. hirta (Taczanowski, 1873), C. inops (Levi, 1963), C. insulsa (Gertsch \& Mulaik, 1936), C. isana (Levi, 1963), C. jequirituba (Levi, 1963), C. kaspi (Levi, 1963), C. koepckei (Levi, 1963), C. lota (Levi, 1963), C. manzanillo (Levi, 1959), C. maraca (Buckup \& Marques, 1991), C. maxima (Keyserling, 1891), C. meraukensis (Chrysanthus, 1963), C. migrans (Keyserling, 1884), C. milagro (Levi, 1963), C. nayaritensis (Levi, 1959), C. oblivia (O. PickardCambridge, 1896), C. orana (Levi, 1963), C. pallipera (Levi, 1963), C. parana (Levi, 1963), C. passiva (Keyserling, 1891), C. pilaton (Levi, 1963), C. pinguis (Keyserling, 1886), C. porteri (Banks, 1896), C. projectivulva (Yoshida, 2001), C. pura (O. PickardCambridge, 1894), C. pusillana (Roewer, 1942), C. pydanieli (Buckup \& Marques, 1991), C. rafaeli (Buckup \& Marques, 1991), C. rapa (Levi, 1963), C. rioensis (Levi, 1963), C. riparia (Blackwall, 1834), C. rostra (Zhu \& Zhang, 1992), C. rostrata (O. Pickard-Cambridge, 1896), C. rupicola (Emerton, 1882), C. schneirlai (Levi, 1959), C. schraderorum (Levi, 1959), C. serenoae (Gertsch \& Archer, 1942), C. sicki (Levi, 1963), C. taeniata (Keyserling, 1884), C. tovarensis (Levi, 1963), C. trinidensis (Levi, 1959), C. uviana (Levi, 1963), C. veruculata (Urquhart, 1886), C. vivida (Keyserling, 1891) and C. zonensis (Levi, 1959). Other than $C$. porteri and C. serenoae, all new combination.

Distribution. Cosmopolitan. Chiefly distributed in America (Buckup \& Marques 1991; Levi 1955, 1959, 1963).

\section{Parasteatoda Archer, 1946}

[Japanese name: O-himegumo zoku]

Parasteatoda Archer 1946, p. 38, established as a subgenus of Theridion; Archer 1950, p. 13, elevated to generic level; Saaristo, 2006, p. 69.

Basal color grayish brown to blackish brown, some are bright orange. Abdomen with broadly and longitudinal cardiac pattern, and some transverse flecks. Carapace oval. Abdomen nearly spherical usually with a small posterior projection. Female genitalia: epigynum with large depression; two openings in both side of the depression; duct relatively longer than that of Henziectypus and Cryptachaea; seminal receptacles nearly spherical. Male palpus: cymbium not extend beyond the alveolus; paracymbium hooded; embolus usually long; conductor short, supporting as embolus guide; median apophysis attached to embolus with which it forms one sclerite; tegulum relatively smaller and subtegulum larger than those of Henziectypus and Cryptachaea.

General appearances and genital organs of many species belonging to this genus were illustrated by Levi (1955, figs. 69-70, 83-84; 1959, figs. 53, 57-60), Chrysanthus (1963, figs. $76-100$; 1975, figs. 168-173), Levi et al. (1982, figs. 2-25), Zhu (1998, figs. 44-46, 50-51, 53-59, 61-64, 6669) and Yoshida (2000, figs. 4-50; 2003, figs. 250-296).

Diagnosis. This genus resembles Henziectypus and Cryptachaea, but is distinguishable from them by cymbium of male palpus not extend beyond the alveolus, and in addition from Henziectypus by median apophysis attached to embolus, from Cryptachaea by smaller and depressed tegulum, and lager subtegulum.

Type species. Theridium tepidariorum C. L. Koch, 1841.

Species included. Forty species and three subspecies are known from the world, chiefly distributed in East to Southeast Asia, and 37 species and a subspecies are newly transferred to this genus.

Parasteatoda angulithorax (Bösenberg \& Strand, 1906), P. asiatica (Bösenberg \& Strand, 1906), P. brookesiana (Barrion \& Litsinger, 1995), P. campanulata (Chen, 1993), P. camura (Simon, 1877), P. celsadomina (Zhu, 1998), P. cingulata (Zhu, 1998), P. culicivora (Bösenberg \& Strand, 1906), P. daliensis (Zhu, 1998), P. decorata (L. Koch, 1867), P. ducta (Zhu, 1998), P. ferrumequina (Bösenberg \& Strand, 1906), P. galeiforma (Zhu, Zhang \& Xu, 1991), $P$. gui (Zhu, 1998), P. hammeni (Chrysanthus, 1963), P. japonica (Bösenberg \& Strand, 1906), P. jinghongensis (Zhu, 1998), P. kaindi (Levi, Lubin \& Robinson, 1982), P. kompirensis (Bösenberg \& Strand, 1906), P. lanyuensis (Yoshida, Tso \& Severinghaus, 2000), P. longiducta (Zhu, 1998), $P$. lunata (Clerck, 1757), P. lunata serrata (Franganillo, 1930), P. mundula (L. Koch, 1872), P. mundula papuana (Chrysanthus, 1963), P. oculiprominens (S. Saito, 1939), P. oxymaculata (Zhu, 1998), P. polygramma (Kulczyński, 1911), P. quadrimaculata (Yoshida, Tso \& Severinghaus, 2000), P. ryukyu (Yoshida, 2000), P. simulans (Thorel, 1875), P. songi (Zhu, 1998), P. subtabulata (Zhu, 1998), P. subvexa (Zhu, 1998), P. tabulata (Levi, 1980), P. transipora (Zhu \& Zhang, 1992), P. tepidariorum (C. L. Koch, 1841), P. tepidariorum australis (Thorell, 1895), P. tesselata (Keyserling, 1884), P. triangula (Yoshida, 1993), P. valoka (Chrysanthus, 1975), $P$. vervoorti (Chrysanthus, 1975) and $P$. wau (Levi, Lubin \& Robinson, 1982). Other than P. camura, P. mundula, $P$. mundula papuana, $P$. tepidariorum and $P$. tepidariorum australis, all new combination.

Distribution. Cosmopolitan. Chiefly distributed in East 
to Southeast Asia (Chrysanthus 1963, 1975; Levi et al. 1982; Yoshida 2000, 2003; Zhu 1998).

\section{References}

Archer, A. F. 1946. The Theridiidae or comb-footed spiders of Alabama. Alabama Mus. Nat. Hist., 22: 1-67.

Archer, A. F. 1950. A study of theridiid or mimetid spiders with descriptions of new genera and species. Alabama Mus. Nat. Hist., 30: $7-40$.

Buckup, E. H. \& Marques, M. A. L. 1991. Aranhas Theridiidae da Ilha de Maracá, Roraima, Brasil, II. Gênero Achaearanea (Araneae). Iheringia, 71: 81-89.

Chrysanthus, Fr. 1963. Spiders from South New Guinea V. Nova Guinea, Zool., 24: 727-750.

Chrysanthus, Fr. 1975. Further notes on the spiders of New Guinea II (Araneae, Tetragnathidae, Theridiidae). Zool. Verhand., 140: $3^{-}$ 50 .

Levi, H. W. 1955. The spider genera Coressa and Achaearanea in America north of Mexico (Araneae, Theridiidae). Amer. Mus. Novitates, 1718: 1-33.

Levi, H. W. 1959. The spider genera Achaearanea, Theridion and Sphyrotinus from Mexco, Central America and the West Indies (Araneae, Theridiidae). Bull. Mus. Comp. Zool., 121: 57-163, pls. $1-26$.

Levi, H. W. 1963. American spiders of the genus Achaearanea and the new genus Echinotheridion (Araneae, Theridiidae). Bull. Mus. Comp. Zool., 129: 187-240, pls. 1-5.

Levi, H. W., Lubin, Y. D. \& Robinson, M. H. 1982. Two new
Achaearanea species from Papua New Guinea with notes on other theridiid spiders (Araneae: Theridiidae). Pacif. Insects, 24: 105113.

Pichard-Cambridge, O. 1882. On new genera and species of Araneidea. Proc. Zool. Soc. London, 1882: 423-442, pls.29-31.

Platnick N. I. 2008. The world spider catalog, version 8.5. American Museum of Natural History, online at http://research.amnh.org/ entomology/spiders/catalog/index html

Saaristo, M. I. 2006. Theridiid or comb spider of the granitic Seychelles Islands (Araneae, Theridiidae). Phelsuma, 14: 49-89.

Strand, E. 1929. Zoological and palaeontological nomenclatorical notes. Acta Univ. Latviensis, 20: 1-29.

Yoshida, H. 1983. A new species of the genus Achaearanea (Araneae: Theridiidae) from Japan. Acta Arachnol., 32: 37-42. (In Japanese with English description)

Yoshida, H. 2000. The spider genus Achaearanea (Araneae: Theridiidae) from Japan. Acta Arachnol., 49: 137-153.

Yoshida, H. 2001. Two new species of the genera Chrysso and Achaearanea (Araneae: Theridiidae) from the Nansei Islands, Japan. Acta Arachnol., 50: 11-14.

Yoshida, H. 2003. The Spider Family Theridiidae (Arachnida: Araneae) from Japan. Arachnological Society of Japan, Osaka, 224 pp. (In Japanese).

Zhu, M. 1998. Fauna Sinica, Arachnida, Araneae, Theridiidae. Science Press, Beijing, ix +436 pp., 1 pl. (In Chinese with English summary)

Received February 28, 2008 / Accepted April 25, 2008 